\title{
STUDY ON SEEPAGE CHARACTERISTICS IN UNSATURATED DECOMPOSED GRANITE SOIL AND THEIR NUMERICAL ANALYSES
}

\author{
佐々木清一*・西 田一彦** \\ By Seiichi SASAKI and Kazuhiko NISHIDA
}

\section{1. 序}

衆知のとおりマサ土は, 風化により変質した構成鉣物 の複雑な組合せから成っているため特殊士の仲間に入れ られ,特に水分との関係は複雑であるとされている.現在 までの上記と関係深い著者らの研究成果を紹介すると, まずマサ土粒子の変質と水分吸着特性について B.E.T. の吸着理論に基ついて検討した結果, 風化度の大きい試 料は, 水分吸着による 自由エネルギーレベルの低下量 （表面自由エネルギー）が著しく，しかもこのような土 粒子の性質は土塊の保水性にも反映する ${ }^{1), 2)}$. つまり, 風化度の大なる試料は, 高い保水性を示すことが明らか にされた ${ }^{3)}$. また, 風化度のパラメーターとして比表面 積を採用し, 土粒子の基本物性と関係つけ不飽和透水係 数を推定する手法を示しだ).

最近, 人工盛土やフィルダムのコア材にこの種の材料 の使用される機会が増えつつある. ところで，周期的に 地下水の浸透, 排水を繰り返し受けるようなコア部にマ サ土が用いられる場合, 土の性質が従来のものとかなり 変化するものと考えられる. そして，このコア部は不飽 和浸透現象の形態をとる.

土の不飽和浸透に関する研究は, 古くから試みられて いる. たとえば, Richards(1931) のポテンシャル理論, そしてこれらの数值解析の可能性を示した Klute (1952) 等を始めとし，現在に至るまで発展の途をたどってい る. 特に, この方面の研究は, 土塞の水分状態と作物の 成育との関係の究明をねらいとする土壌物理の分野にお いて，数多く取り扱われており土木工学の分野でも，最 近研究が進められている.

不飽和浸透の数値解析の手法にウエイトをおいた研究

* 正会員 和歌山工業高等専門学校助教授 土木工学科

** 正会員 工博 関西大学教授 工学部土木工学科
として，F.E.M. を駆使した飽和一不飽和浸透流の解析 ${ }^{5)}$ や地盤の応力・変形と浸透流の解析 ${ }^{6}$ 等がある. さらに, 少し異色の実験的研究として, 不飽和土中における熱と 水分の移動 ${ }^{7}$, 舗装部の温度変化による路盤内の水分移 動機構の解明 ${ }^{8)}$, パワーケーブルに発生する熱によるケ 一ブルの破損防止の目的で, 埋め戻し土の保水性を確保

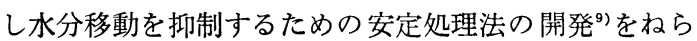
いとした研究等が挙げられる.

これらの研究の中で, いずれも共通する点は不飽和土 の浸透特性を支配するパラメーターの計測手法が十分確 立していないことであり，その実測值の集積も少なく高 度に開発された解析手法を生かすためにも，この方面の 研究が重要である.

そこで, 本論文では, マサ土のような特殊性を もつ土が Fig. 1 に揭げ るように盛土やフィルダ ムのコア材として使用さ れた場合を想定し，土層

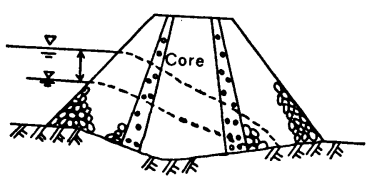

Fig. 1 Filldam core under variable water level. カラムを使用した吸排水の繰り返し実験を行った. そし て, 風化度と不飽和浸透のパラメーターとの関係を把握 するとともに，特に風化度の大きいマサ土について，吸 排水時の沈下特性を測定し，体積変化を考えた不飽和浸 透方程式による解析を試み合理的解析法を見出すように 努めた.

\section{2. 試料の基本物性と実験方法}

本実験に使用した試料は，和歌山県日高川産の川砂と 風化度の異なる 3 種類のマサ土である. マサ土は, 大阪 三日市市と奈良県生駒山において採取したものであり， 自然の鉱物組成を有するものである.

これらの試料は, 自然乾燥後, 過度に破砕しないよう 
にときほぐし $2000 \mu \mathrm{m}$ ふるいでふるい分けした. そし て,試料の風化度の尺度は見かけ比重 $G_{a}$ 主 1), 比表面積, 強熱減量の値を採用し, それらの值を総合して判断し た. その結果, 川砂, マサ土 $1,2,3$ と番号の大きい順 に風化度が高くなる. 特に, この比表面積は水銀圧入ポ ロシメータで 1〜1000 kg/cm²（98 kPa〜98 MPa）まで 加圧し測定しているため, その値の大きい試料は土粒子 内外表面に複雑な凹凸を有することを示唆している. 一 方, 日本統一分類法では, 一様に砂質土に分類されるが 中でもマサ土 3 は MI となり高い圧縮性を有する土に分 類される. 特に，この種の土をコア材に使用された場合 を想定し解析の対象とした.

盛土あるいはフィルダムコアにマサ土が使用され，上 流側土中の水位が変動する場合を予想したモデル実験を 行った. 装置は角柱の塩化ビニル製容器(断面 $100 \times 100$ $\mathrm{mm}^{2}$, 肉厚 $5 \mathrm{~mm}$, 長さ $800 \mathrm{~mm}$ ) で，その中にできる だけ均一な密度になるように試料を詰めた. まず, 吸水 は Fig. 2 に示される給水装置から水頭 $80 \mathrm{~cm}$ （動水勾 配 1) のもとで容器の底部にあるポーラスストーンの位 置まで水位を上げておき浸透を開始した． 砂では約 1 日，マサ土は約 2 日間行い $70 \mathrm{~cm}$ の位置にあるトラン スジュサーのサクションが 0 10 cm の範囲に入ったと きをもって飽和とみなし，給水を停止しただちに排水コ ックを開き排水実験に移った. このような要領で約 1 か 月間吸排水の繰り返し実験を行った.

吸排水実験中に生じる沈下は，変位トランスジュサー （最大変位 $100 \mathrm{~mm}$, 精度 $3 / 1000 \mathrm{~mm}$ ) により, サクシ ョンは圧カトランスジュサー（最大圧力 $\pm 1 \mathrm{~kg} / \mathrm{cm}^{2}(98$ $\mathrm{kPa}$ )，精度 $\pm 2 / 1000 \mathrm{~kg} / \mathrm{cm}^{2}(196 \mathrm{~Pa})$ ) の先端に直径 6 $\mathrm{mm}$, 長さ $50 \mathrm{~mm}$ の円筒形のセラミック製チップ (Airentry value $\left.2 \mathrm{~kg} / \mathrm{cm}^{2}(196 \mathrm{kPa})\right)$ を取り付け同図に示

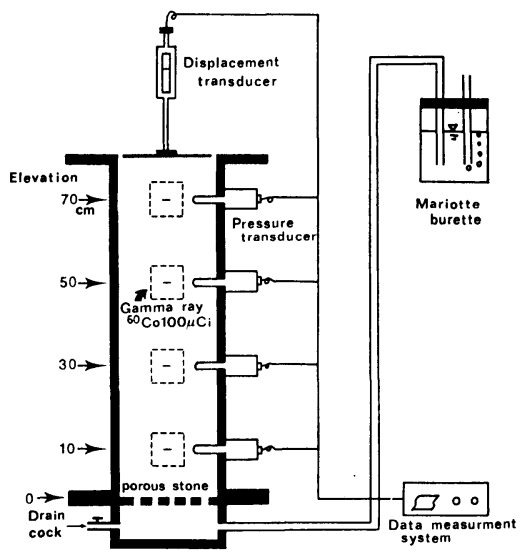

Fig. 2 Layout of experimental apparatus.

注 1）見かけ比重 $G_{a}$ とは, 土粒子内部の空隚も土粒子容積 の一部としたときの值であり，この值が小さいことは土 粒子内空隌が多いことを意味する.
される配置により自動データシステムで昼夜にわたり測 定を遂行した．なお，測定間隔は吸水実験 3 分，排水実 験 1 時間である. さらに, 試料容器と土の摩擦をできる だけ軽減するため, その壁面にワックスを塗り試料表面 には $0.13 \mathrm{~kg} / \mathrm{cm}^{2}(12.7 \mathrm{kPa})$ のおもりを載荷した.

ところで, 本研究のごとく土中の任意の深さにおいて 時々刻々変化する水分量を簡単に精度よく，乙かも長期 にわたり計測する手法として R.I (Radio Isotope)によ る法が現時点で最も効果的と考えられる. その理由は非 破壞法であるために試料を乱すことなく，その密度や含 水比の物性値を繰り返し測定できる. しかも，盛土やフ イルダム現場においてもボーリング孔を利用し測定可能 である.このような利点から, 含水比の計測は $r$ 線密度 計を用いた. そして,この装置は角柱の任意の位置へ上 下に移動し, 試料のどの位置でも測れるよう工夫した. 線源には低キューリの ${ }^{60} \mathrm{Co} 100 \mu C_{i}$ を用い GM 管で 30 秒間の $r$ 線量を計測した.

$r$ 線利用による含水比の決定はあらかじめ作成される 校正曲線に左右される. したがって，本研究ではこの種 の曲線は 試料の種類に 左右されないとの 報告 ${ }^{10)}$ むある が，マサ土の複雑な物性と水分との関係を考え試料ごと に作成した. 特に, 校正曲線を作る実験はマサ土の破砕 による構造変化の影響を考え多数の試料による非絽り返 し突固め法で行った. そして, 含水比の計算は乾燥密度 一定という前提で行われるため実験時に校正曲線を作っ たときの乾燥密度になるように試料を詰めておく必要が ある.この煩雑さを解消するために, 各種の密度につい てただちに含水比が得られる実験式 (1) を用いだ).

$$
w=\frac{R+0.163 \gamma_{d}-0.856}{\alpha}
$$

ただし, $w$ : 含水比 $(\%), R$ : 計数率比, $r_{d}$ : 乾燥密 度 $\left(\mathrm{Mg} / \mathrm{cm}^{3}\right), \alpha:$ 実験式の勾配

式 (1) に試料の実験前の乾燥密度 $r_{\boldsymbol{d}}$ を代入すれば含 水比 $w$ が求められる. ただし, 著しい沈下の生ずる試

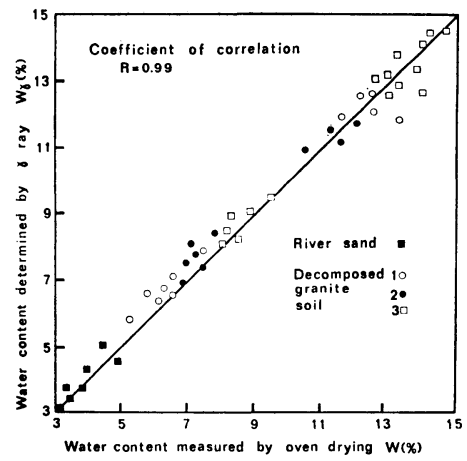

Fig. 3 Comparison of results determined by oven drying and gamma ray method. 
料であれば修正した乾燥密度 $r_{d}$ を採用しなければなら ない。

Fig. 3 は $r$ 線と炉乾燥法による含水比の值をプロッ トしたものである.これらの相関係数 $R$ は 0.99 であ り密接な関係をもつことを意味する. さらに， $r$ 線の誤 差の要因として放射線のゆらぎにかかわるものが考えら れるため, 計数率比 $R$ の誤差を調べた結果， \pm 0.001 と一定であった. そして，この值と関数関係にある式 (1) の平均二乘誤差を誤差伝播の法則から求め炉乾燥法 の值と比較すると, 小数点以下 1 桁くらいのばらつきで あり他の含水比測定法と比べても, 本手法の誤差は十分 許容できるものと考えられる ${ }^{11}$.

\section{3. 風化度と不飽和浸透特性}

試料の表面に設置した 沈下計の動きを観測するため られるコラップス現象といわれている沈下が生じる ${ }^{12)}$. そして, 排水過程に入ると沈下は徐々に進行する. ここ で, 排水を中止し数日間静止の状態にしておくと, 沈下 の割合は吸排水過程よりも少ないが，やはり生じる.

今回の実験の目的は, 特に圧縮変形中の透水特性を明

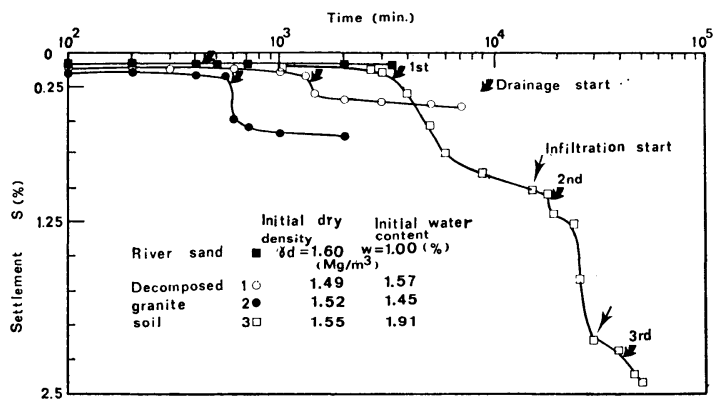

Fig. 4 Settlement properties of samples during wet-drainage experiment. に,まず吸排水実験を行った.吸水過程で盛土に一般にみ

らかにすることであり, 大部分の沈下が排水中に起こる よう吸水後ただちに排水を開始した.

Fig. 4 は吸排水過程の沈下特性を示したものである. この図によれば，マサ土 3 の沈下量は川砂やマサ土 1,2 のそれよりもきわめて大きく, 繰り返し吸排水実験を行 うと累積沈下はますます増加する. そして, その沈下量 は初期の含水比や密度にも関係するはずである.

特に, 排水中の沈下はサクションの増加に伴う有効応 力の増分と粒子間レベルの構造変化によるものといわれ ている ${ }^{13), 14) .}$

コア材に風化度の大なるマサ土を使用する場合, 締め 固め密度が小さいと沈下量が大きくなることが予想され る. したがって, 施工管理が重要であるとともに土構造 物の浸透を解析するうえで, 沈下による体積変化が問題 となる. すなわち, 通常の不飽和浸透方程式ではなく体 積変化を考えた不飽和浸透方程式による解析の必要性を 示唆するものである. そこで, 特に, 排水時に着目しそ の浸透特性について調べることにする.

Fig. 5 は体積含水率 $\theta$ の経時変化とそれに及ぼす風 化度の影響を表わしたものである. 同図から，体積含水 率 $\theta$ は排水時間の経過とともに徐々に小さくなり, また 土柱の上部の值は下部のそれより小さい。そして, 体積 含水率 $\theta$ は排水直後に大きい変化がみられ, その後長時 間経過後のその変化は小さい。さて, 各試料の体積含水 率 $\theta$ の分布に対し風化度の影響をみると風化度の大なる マサ土 3 は，川砂や他のマサ土よりもきわめて高い值を 呈している.

排水時間に対応しサクション $\phi$ の值を測定した結果 が Fig. 6 である. 各試料のサクション $\phi$ は, 排水時 間の経過とともに增加し, また土柱の上部ほどその值は 大きい．特に，風化度の大きいマサ土 3 はきわめて高い サクション $\phi$ を示している. そして, 長時間経過後の これらの変化も体積含水率 $\theta$ と同様に小さい.ここで, Fig. 5 と Fig. 6 を対比させると時間の経過に従って

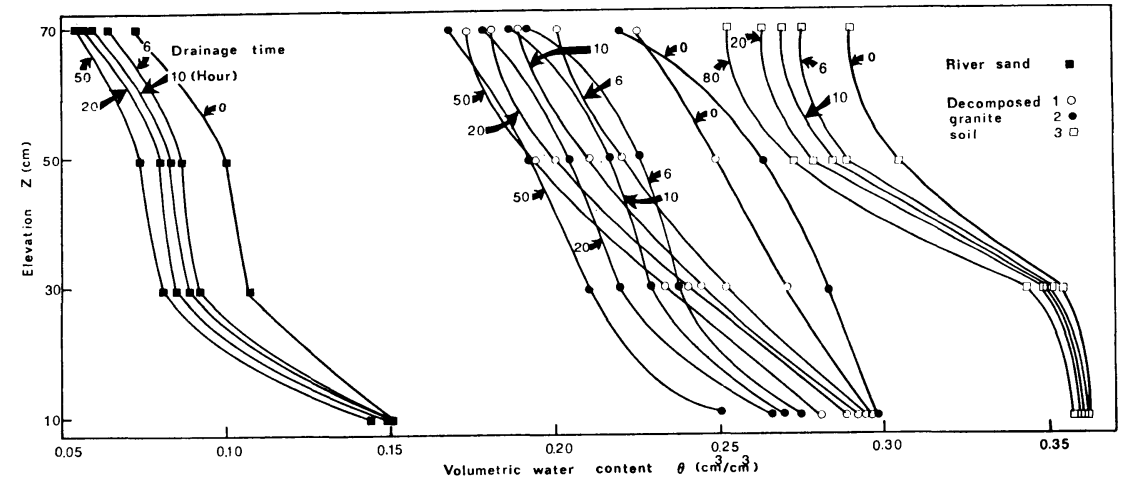

体積含水率 $\theta$ は減少し 反対にサクション $\psi$ は 増加することがわかる. つまり，風化度の大きい 試料ほど，高い体積含水 率 $\theta$ に招いても高いサ クション $\psi$ の值がみら れることが特長である.

Fig. 7 は試料の水分 保持曲線を示したもので ある.両者の関係におい ても風化度の影響は明ら

Fig. 5 Volumetric water content distribution of samples during drainage. 


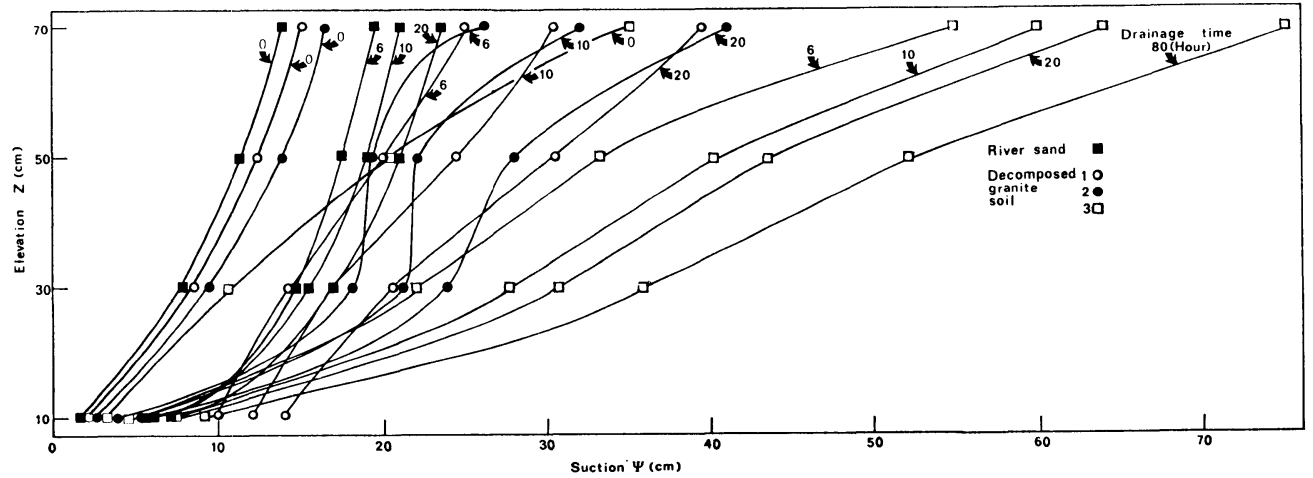

Fig. 6 Suction distribution of samples during drainage.

かである.つまり，サクション $\psi$ 一定の条件で風化度 の大きい試料は高い体積含水率 $\theta$ を示す. ところで，こ の図において曲線の勾配 $d \theta / d \psi$ は比水分容量といわ れ，水分拡散係数 $D$ や体積含水率 $\theta$, サクション $\phi$ の 解析に必要な量である. 本実験の場 合, $\psi=0,100 \mathrm{~cm}$ 付近では $d \psi / d \theta$ の值が $\infty$ となり Klute 型の拡散方程 式は，この近傍では使えないことになる.

\section{4. 圧縮性に伴う間㭞比変化とその不飽和漫透 を支配するパラメーター}

不飽和浸透解析を行うためには，土のパラメーターの 正しい計測結果とその集積が必要である. 従来から，各 種の方法が提案されているが，本研究のおもな対象であ る体積変化を伴う場合のデータはそしい，そこで，排水 中の透水係数, 拡散係数と風化度の関係, さらに体積変 化を取り入れたパラメーターについて以下検討する.

Fig. 8 は不飽和透水係数 $K$ と体積含水率 $\theta$ の関係 を示すものであり， $K$ は式 (2) によって求めた ${ }^{15}$.

$$
K=\frac{\left(\int_{0}^{z} \frac{\partial \theta}{\partial t} d z\right)_{z, t}}{\left(\frac{\partial \psi}{\partial t}+1\right)_{z, t}}
$$

各試料の不飽和透水係数 $K$ は，体積含水率 $\theta$ と深く 関係し体積含水率 $\theta$ の増減により大幅に変化する. そし て，風化度の大きい試料ほど高い体積含水率 $\theta$ にもかか わらず不飽和透水係数 $K$ は小さくなっている. また, 同じ体積含水率 $\theta$ でも不飽和透水係数 $K$ は，風化度の 大なるものほど小さい傾向を示している.このような現 象は，マサ土粒子表面に含まれている多数の凹凸やイン ク瓶形の空孔と関倸し，また拘束水の存在を暗示するも のと考えられ，これらの要素も一種の抵抗力となってい るものと思われる. さらに，両者の関係は土中水分の減 少と増加過程では異なるといわれ，いわゆるヒステリシ スを有する.これは水分保持曲線の特性に支配されるも

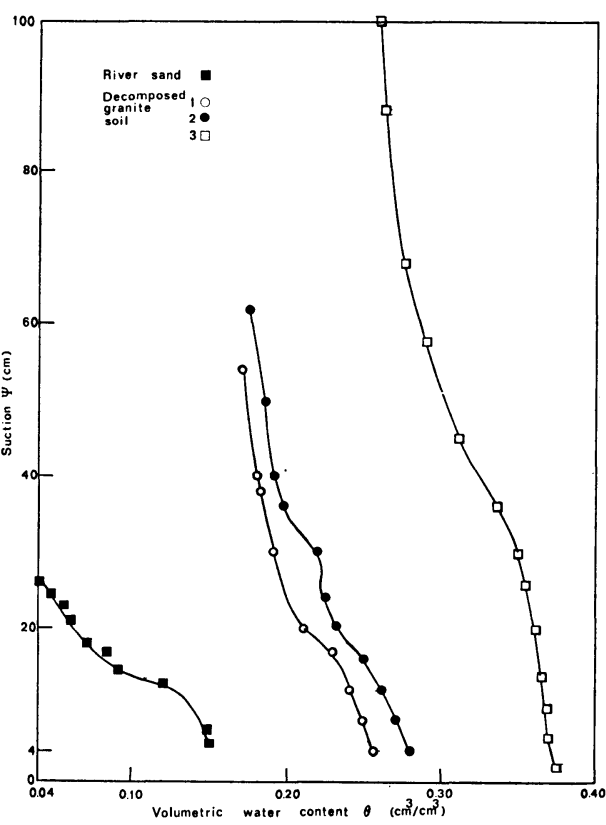

Fig. 7 Soil moisture characteristic curve of samples during drainage.

のである.しかし，このヒステリシスは体積含水率 $\theta$ を 用いると無視し得るほど小さいがサクションとの関係で は無視できない. その理由は, 土中のインク瓶形間隚や 間隚中を水が前進するときと後退するときの接触角の違 いによるメニスカスの違いであると報告されている ${ }^{16)}$. いま，不飽和透水係数 $K$ が測定法により差があるかど うかを検討するため，既報の飽和度を人工的にコントロ 一ルした定常法と非定常法との傎を比較すると，ある程 度の幅をもちながらばらついてはいるが不飽和透水係数 $K$ の変化の傾向は一致している. したがって，著者ら がすでに提案した不飽和透水係数を表わす式による非定 常浸透流の解析への利用も可能となる ${ }^{4)}$.

体積含水率 $\theta$ やサクション $\phi$ の分布を予測するに は，不飽和透水係数 $K$ と体積含水率 $\theta$ の関係を正しく 
把握し 両者をある 関数で表現しなければならない. 最 近, この種の関係を求めるために, 相対透水係数 $K_{r}$ と 有効飽和度 $S_{e}$ の関係で 表現する方法があり， Fig. 9 はFig. 8 を式 (3) を用いて再整理したものである ${ }^{17)}$.

$$
\left.\begin{array}{l}
K_{r}=K / K_{\text {sat }} . \\
S_{e}=\left(\theta-\theta_{r}\right) /\left(\theta_{\text {sat. }}-\theta_{r}\right)
\end{array}\right\}
$$

ただし, $K_{r}$ : 相対透水係数, $K$ : 不飽和透水係数 $(\mathrm{cm} /$ $\mathrm{s}), K_{\mathrm{sat}}$ ：飽和透水係数 $(\mathrm{cm} / \mathrm{s}), S_{e}$ : 有効飽和度, $\theta$ : 体積含水率 $\left(\mathrm{cm}^{3} / \mathrm{cm}^{3}\right), \theta_{r}$ : 最小体積含水率 $\left(\mathrm{cm}^{3} / \mathrm{cm}^{3}\right)$, $\theta$ sat. : 飽和体積含水率 $\left(\mathrm{cm}^{3} / \mathrm{cm}^{3}\right)$, ここで $\theta_{r}$ は吸着水 や拘束水という浸透に直接関与しない水分であり $\mathrm{pF} 3.3$ の水分とした.

風化度の異なるマサ土の場合でも, 両者は両対数紙上 でほぼ直線的関係を示しており，これらを関数化すれば 不飽和透水の解析に役立つものと考えられる.

Fig. 10 は水分拡散係数 $D$ と体積含水率 $\theta$ の関係を 表わしたものである. この拡散係数 $D$ は，ある体積含水 率 $\theta$ に対する Fig. 8 の $K$ と Fig. 7 から得られる $d \theta / d \phi$ との商で定義される. そして, 水分拡散係数 $D$ は体積含水率 $\theta$ に左右され体積含水率 $\theta$ の増加により 大きくなる. さらに，この值は風化度の大きい試料ほど 小さくなる.

3. で風化度の大きい試料ほど沈下が著しい事実を明 らかにした. 排水中の沈下を間隚比 $e$ に直し時間的変化

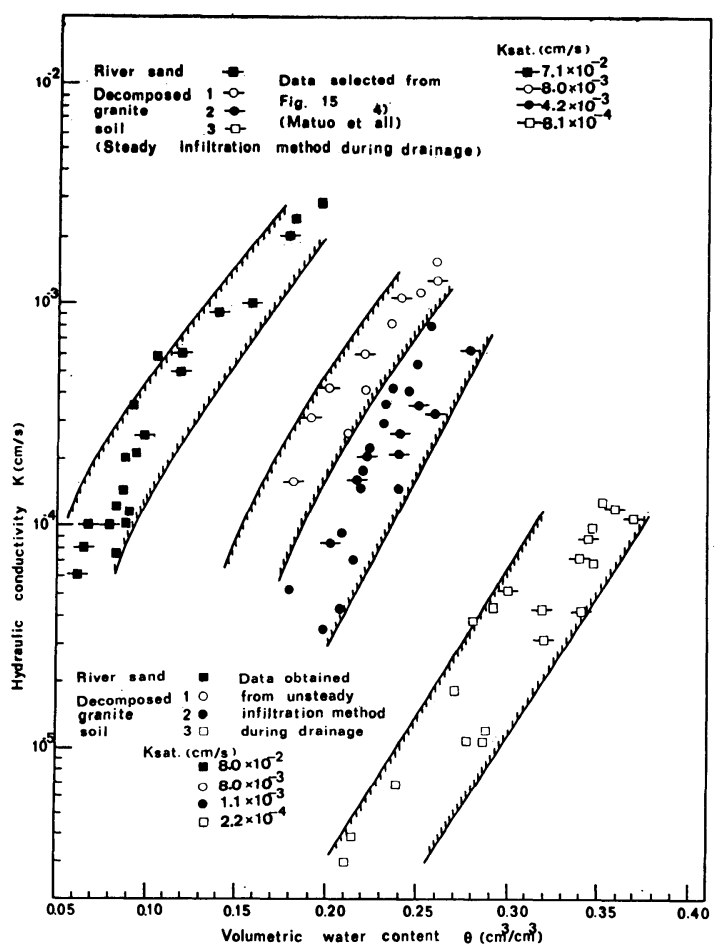

Fig. 8 Relationship between hydraulic conductivity and volumetric water content of samples.
として表わした結果が

Fig. 11 である.この結 果, 間偗比 $e$ は排水時間 の経過とともにしだいに 小さくなる.ところで, 間隚比 $e$ は厳密には樑さ ごとに異なるものである が，土中の変位を測定す ることが困難であるた め, 深さ方向に対しても 一様であると考えた.

浸透中に体積変化を生 ずる場合，体積含水率 $\theta$ でなく体積含水比 $\vartheta=$ $V_{w} / V_{s}$ の変化を追跡す る方が合理的である.こ こに, $V_{w}$ は土中水の体 積を表わし， $V_{s}$ は土粒

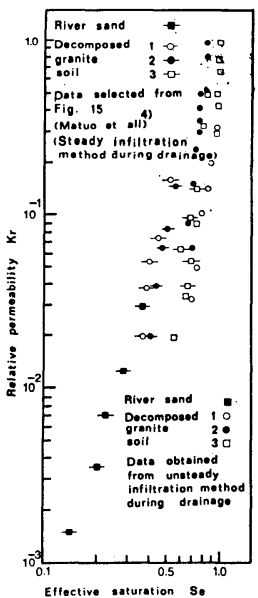

Fig. 9 Relationship between relative permeability and effective saturation.
子の体積であり体積含水比 $\vartheta$ は $\vartheta=(1+e) \theta^{\prime}$ という関 係になる.ここで注意を払わねばならない点は, 間嚐比 $e$ は Fig. 11 の值を用い, また体積含水率 $\theta^{\prime}$ の計算 は式 (1) の中に含まれる乾燥密度 $r_{d}$ を一定とするので はなく, 逐次変化する間嚐比 $e$ を乾燥 密度 $r_{d}=G_{s}$.

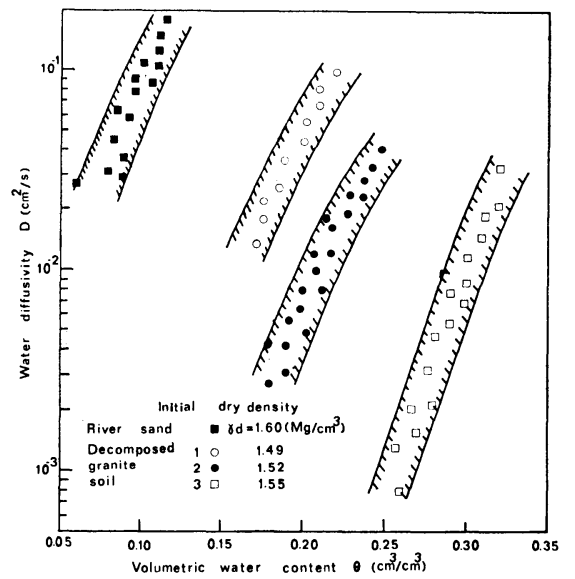

Fig. 10 Relationship between water diffusivity and volumetric water content of samples.

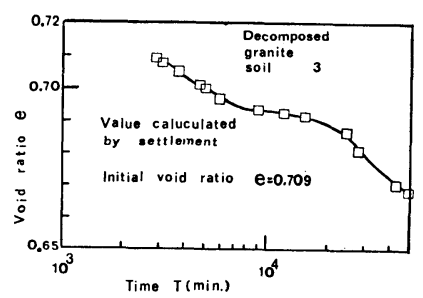

Fig. 11 Change of void ratio with time during drainage. 


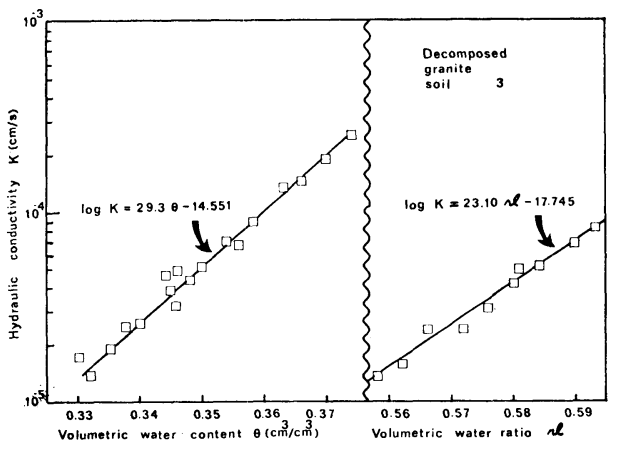

Fig. 12 Relation of hydraulic conductivity for volumetric water content and volumetric water ratio.

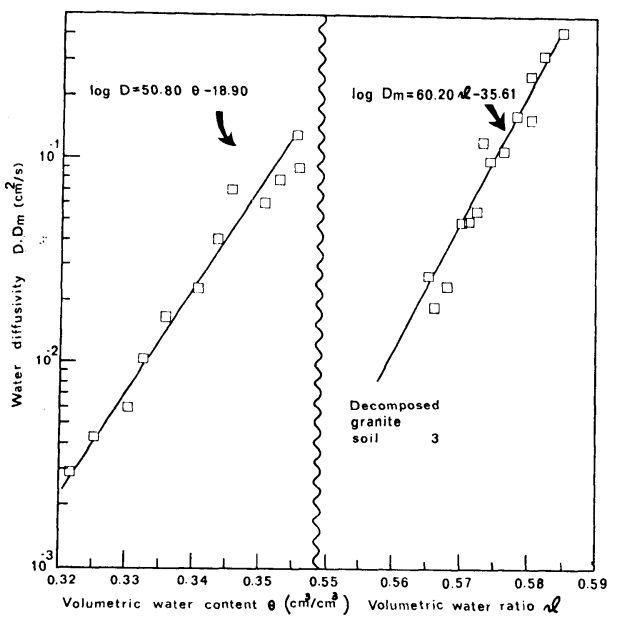

Fig. 13 Relation of water diffusivity for volumetric water content and volumetric water ratio.

$\gamma_{w} / 1+e$ に修正して算出することである.

Fig. 12 は不飽和透水係数 $K$ と体積含水率 $\theta$, 含水 比 のの関係を示した. 特 に, $K$ と $\vartheta$ 関係は圧縮 沈下中の関係を示すもので あり解析の便利さを考えて 直線で近似した. 同じよう に, Fig. 13 は水分拡散係 数 $D, D_{m}$ との関係を表わ したものである.ここに,水 分拡散係数 $D_{m}$ は $D_{m}=$ $(K / 1+e) \cdot(d \psi / d \vartheta)$ の関係 で表わされ， $\phi / d \vartheta$ の値は 体積含水比による水分保持 曲線から求めた. したがっ て，3. で指摘したように， $d \psi / d \vartheta$ が $\infty$ 付近は省略し
た.

Fig. 14 は水分拡散係数 $D, D_{m}, D_{m}{ }^{\prime}$ とサクション $\phi$ の関係をプロットしたものである. この図中で，水分拡 散係数 $D_{m}{ }^{\prime}$ は $D_{m}{ }^{\prime}=(1+e) \cdot D_{m}$ の 関係 となる. 同図 から明らかなように, 拡散係数はサクション $\phi$ の増加 とともに急激に小さくなり, 両者の関係は直線で近似さ れる.

\section{5. 圧縮性を考えた不飽和浸透方程式による解析}

マサ土の体積含水率とサクションの実測データに対し て, 得られたパラメーターを入力し数值解析を以下のよ うな手順で試みた。 まず，圧縮性を考えない通常の鉛直 浸透の不飽和方程式を用いてその解析を行った. そし て,これらの式は Klute の拡散方程式とよばれ式 (4), (5) で与えられる.

体積含水率 $\theta$ に関して,

$$
\frac{\partial \theta}{\partial t}=\frac{\partial}{\theta z}\left(D \frac{\partial \theta}{\partial z}\right)+\frac{\partial K}{\partial z}
$$

サクション $\phi$ に関して,

$$
\frac{\partial \psi}{\partial t}=\frac{\partial}{\partial z}\left(D \frac{\partial \psi}{\partial z}\right)+\frac{\partial D}{\partial z}
$$

ここに, 式 (4) において水分拡散係数 $D$ は体積含水率 $\theta$ の関数であり Fig. 13 で示される実験式で与えられ， 不飽和透水係数 $K$ はやはり体積含水率 $\theta$ の関数として Fig. 12 の式で表わされる. また, 式（5）において水 分拡散係数 $D$ は，サクション $\phi$ の関数で Fig. 14 の式 で与えられる.そして，これらの式は，いろいろな地点 の時々刻々と変化する水分とサクションを知るときに用 いられる.

さて, 本研究の解析対象は沈下の著しいマサ土であ る. すでに 3., 4. で指摘したとおり排水中に時々刻々 と変化する沈下, すなわち間隙比 $e$ の変化を考えた方程 式に基づく解析を必要とする. したがって，式 (4),(5) はマサ土の排水時の 解析に対して 適当でない。 ところ で，浸透中に間隚比の変化を伴う解析手法は，従来から 膨潤土中の水分移動の研究分野で開発され, 次のように 説明されている ${ }^{18}$.

鉛直一次元流れにおいて， $z$ 軸を固定し土は表面から 下方に圧縮沈下するものとして, 物質座標 $m$ を式 (6) のように定義して用いる.

物質座標を採用する理由は, 変形を微小とし無視せず 有限変形とすることである．そして，体積変化を考えた 不飽和浸透方程式は, 体積変化を考えない場合の解析と 同様に取り扱われる.

$$
m_{z}=\int_{0}^{z}(1+e)^{-1} d z
$$


ここで, $e$ は間隚比である. そして, このとき連続の 式は式 (7) で表わされる.

$$
\frac{\partial \vartheta}{\partial t}=-\left(\frac{\partial q_{z}}{\partial m_{z}}\right)
$$

ここに, $\vartheta$ は体積含水比, $m_{z}$ は物質座標 $m$ の $z$ 成 分, $q_{z}$ は土中水の移動フラックス $q$ の $z$ 成分である.

土中水の移動フラックスは, Darcy の法則により式 (8) で与えられる.

$$
q_{z}=-K \frac{\partial \Phi}{\partial z}
$$

そして, 式 (8) のゅは水の全ポテンシャルを意味し 式 (9) となる.

$$
\Phi=\phi+z-\Omega
$$

ここに， $\phi$ はマトリックスポテンシャル（通称サクシ ヨンとよぶ）といわれ，土粒子と水分との相互作用に支 配される. $z$ は位置， $\Omega$ は土かぶりによるポテンシャル である.そして， $\Omega$ は，特に式 (10) で関係づけられる.

$$
\Omega=P(0)+\int_{0}^{z} r d z
$$

ただし， $P(0)$ は荷重によるもので本実験では一定で ある. $r$ は土の見掛滵度である. ところで, 式 (8), (9), (10)から式 (8) は式 (11) に書き直すことができる.

$$
q_{z}=-K\left(\frac{\partial \psi}{\partial z}+1-r\right)
$$

さらに, 式 (6), (7), (11) の組合せにより体積含水比 $\delta$ に関する式を誘導することができる.

$$
\begin{aligned}
\frac{\partial \vartheta}{\partial t} & =\frac{\partial}{\partial m_{z}}\left(K \frac{\partial \psi}{\partial z}\right)+\frac{\partial K}{\partial m_{z}}(1-r) \\
& =\frac{\partial}{\partial m_{z}}\left(K \frac{\partial \phi}{(1+e) \partial m_{z}}\right)+\frac{\partial K}{\partial m_{z}}(1-r) \\
& =\frac{\partial}{\partial m_{z}}\left(K \frac{\partial \phi}{\partial \vartheta} \cdot \frac{\partial \vartheta}{(1+e) \partial m_{z}}\right)+\frac{\partial K}{\partial m_{z}}(1-r) \\
& =\frac{\partial}{\partial m_{z}}\left(D_{m} \frac{\partial \vartheta}{\partial m_{z}}\right)+\frac{\partial K}{\partial m_{z}}(1-r) \cdots \cdots(12)
\end{aligned}
$$

ここに, $D_{m}$ は $D_{m}=(K / 1+e) \cdot(\partial \psi / \partial \vartheta)$ であり圧縮 沈下時の水分拡散係数を意味し, 体積含水比 として Fig. 13 の実験式で与えられる. 同様にして, 不飽和透水係数 $K$ も Fig. 12 に示されている式で表 わされる.

サクション $\phi$ に関する式は, 式 (12) の両辺を $\partial \vartheta / \partial \phi$ で除することにより導かれる.

$$
\begin{aligned}
\frac{\partial \psi}{\partial \vartheta} \cdot \frac{\partial \vartheta}{\partial t}= & \frac{\partial}{\partial m_{z}}\left(D_{m} \frac{\partial \vartheta}{\partial m_{z}} \cdot \frac{\partial \psi}{\partial \vartheta}\right) \\
& +\frac{\partial \psi}{\partial \vartheta} \cdot \frac{\partial K}{\partial m_{z}}(1-r) \\
\frac{\partial \psi}{\partial t}= & \frac{\partial}{\partial m_{z}}\left(D_{m} \frac{\partial \psi}{\partial m_{z}}\right)+\frac{\partial D_{m}^{\prime}}{\partial m_{z}}(1-r)
\end{aligned}
$$

ここに, $D_{m}{ }^{\prime}$ は $D_{m}{ }^{\prime}=K \partial \phi / \partial \vartheta$ であり $D_{m}$ とともに
サクション $\phi$ の関数として Fig. 14 の式で与えられる. 式 (12), (13) は浸透中に変化する間嚐比 $e$ と湿潤密度 $r$ を含む式である，しかし，序文でも述べたように水位 変動を伴うコア内の湿潤密度は一定ではなく, 大幅な変 化が予想される.このような事実はフィルダムの現位直 調査においても明らかにされている(19). そこで, 式(12)， （13）の中の湿潤密度 $r$ は，一定ではなく沈下による間 隚比 $e$ の変化により変化する. したがって, $e$ と $\theta^{\prime}$ から

$$
r^{\prime}=\frac{G_{s}}{1+e} r_{w}+\frac{\theta^{\prime}}{100}
$$

に修正した值を採用すべきと考える．そして， $r^{\prime}$ は位 置と体積含水比により変化するものと考えるならば，ま ず体積含水比 $\vartheta$ 場合は式 (14) のように修正すべきで ある.つまり，式 (12) において，

$$
\frac{\partial K}{\partial m_{z}}(1-r)=\frac{\partial K}{\partial m_{z}}-\left(K \frac{\partial r^{\prime}}{\partial m_{z}}+r^{\prime} \frac{\partial K}{\partial m_{z}}\right) \cdots
$$

同様に, サクション $\phi$ の場合式 (13) において,

$$
\frac{\partial D_{m}^{\prime}}{\partial m_{z}}(1-\gamma)=\frac{\partial D_{m}^{\prime}}{\partial m_{z}}-\left(D_{m}^{\prime} \frac{\partial \gamma^{\prime}}{\partial m_{z}}+\gamma^{\prime} \frac{\partial D_{m}^{\prime}}{\partial m_{z}}\right)
$$

したがって，式（12）は式（16）となる.

$$
\begin{aligned}
\frac{\partial \vartheta}{\partial t}= & \frac{\partial}{\partial m_{z}}\left(D_{m} \frac{\partial \vartheta}{\partial m_{z}}\right)+\frac{\partial K}{\partial m_{z}} \\
& -\left(K \frac{\partial r^{\prime}}{\partial m_{z}}+r^{\prime} \frac{\partial K}{\partial m_{z}}\right) \cdots
\end{aligned}
$$

また，式（13）は式（17）で表わされる.

$$
\begin{aligned}
\frac{\partial \psi}{\partial t}= & \frac{\partial}{\partial m_{z}}\left(D_{m} \frac{\partial \psi}{\partial m_{z}}\right)+\frac{\partial D_{m}^{\prime}}{\partial m_{z}} \\
& -\left(D_{m}^{\prime} \frac{\partial r^{\prime}}{\partial m_{z}}+r^{\prime} \frac{\partial D_{m}^{\prime}}{\partial m_{z}}\right)
\end{aligned}
$$

そこで, 式 (4),(5)，(12)，(13)，(16)，(17）の差分近似 式を求め検討した. これらの詳細は，6.に譲る.いま， Crank-Nicholson 法により一例として, 式 (16), (17) の 差分式を求めたところ式 (18), (19) のとおりである.こ こに, $R=\Delta t / \Delta m_{z}{ }^{2}$ である.

体積含水比 $\vartheta$ については,

$$
\begin{aligned}
& A \vartheta_{i+1}^{n+1}+B \vartheta_{i}^{n+1}+C \vartheta_{i-1}^{n+1} \\
& \quad=-A \vartheta_{i+1}^{n}+D \vartheta_{i}^{n}-C \vartheta_{i-1}^{n}+E
\end{aligned}
$$

そして,この式の各係数は, 次のとおりである.

$$
\begin{aligned}
A= & -R D_{m}\left(\vartheta_{i+1 / 2}^{n}\right) \\
B= & 2+R D_{m}\left(\vartheta_{i-1 / 2}^{n}\right)+R D_{m}\left(\vartheta_{i+1 / 2}^{n}\right) \\
C= & -R D_{m}\left(\vartheta_{i-1 / 2}^{n}\right) \\
D= & 2-R D_{m}\left(\vartheta_{i-1 / 2}^{n}-R D_{m}\left(\vartheta_{i+1 / 2}^{n}\right)\right. \\
E= & 2 R \Delta m_{z}\left\{K\left(\vartheta_{i+1 / 2}^{n}\right)-K\left({ }_{i-1 / 2}^{n}\right)\right\}-2 R \Delta m_{z} \\
& \cdot\left[K\left(\vartheta_{i}^{n}\right)\left\{\gamma^{\prime}\left(\vartheta_{i+1 / 2}^{n}\right)-\gamma^{\prime}\left(\vartheta_{i-1 / 2}^{n}\right)\right\}\right. \\
& \left.+\gamma^{\prime}\left(\vartheta_{i}^{n}\right)\left\{K\left(\vartheta_{i+1 / 2}^{n}\right)-K\left(\vartheta_{i-1 / 2}^{n}\right)\right\}\right]
\end{aligned}
$$

式（18）は，湿潤密度 $r^{\prime}$ に対する体積含水比 の関 係を必要とし，これらは Fig. 15 で表わされ，つまり 


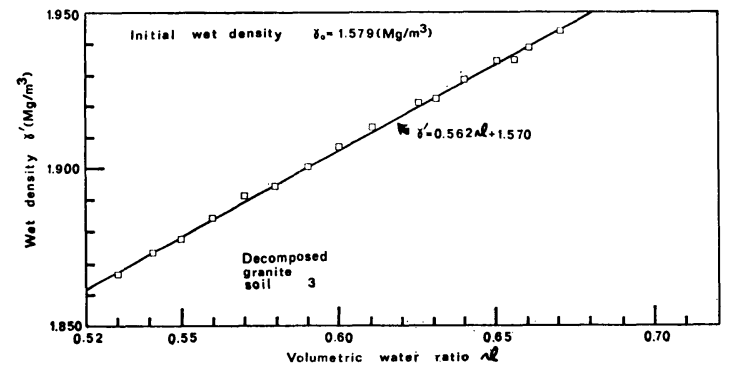

Fig. 15 Relationship between wet density and volumetric water ratio of samples.

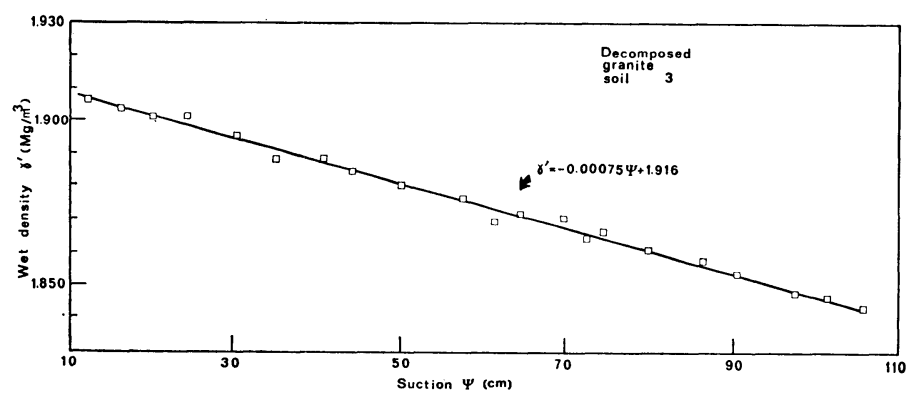

Fig. 16 Relationship between wet density and suction of samples.
(3) 初期条件 : $t=0, m_{z}>0, \psi=\phi_{i}$ （初期サクション 分布）

(4) 境界条件 : $t>0, m_{z}=0, \phi=0, m_{z}=\int_{0}^{80}(1 / 1$

$+e) d z, \phi=\phi(t)$

特に, この種の式は, その係数が未知数であるため直 接解を求めるわけにはいかない.これらの解法として, いろいろ提案されているが最も収束のよい絽返し計算 法 ${ }^{20)}$ を採用し解析した.

\section{6. 解析結果の検討}

5. で述べた各種の不飽和浸透方程式 による解を検討するために, 繰り返し 3 回吸排水実験を行ったマサ土 3 の排水時 の值と比較検討するものである.

Fig. 17 は体積含水比 $\vartheta$ の変化を物 質座標 $m_{z}$ を用いて整理したものであ る. $m_{z}$ は, 通常の座標 $z$ から沈下分を 差し引き式 (6) で再計算を行った. 図 $r^{\prime}$ はの増減により直線的に変化する.

サクション $\phi$ については,

$A^{\prime} \psi_{i+1}^{n+1}+B^{\prime} \psi_{i}^{n+1}+C^{\prime} \psi_{i-1}^{n+1}$

$=-A^{\prime} \psi_{i+1}^{n}+D^{\prime} \phi_{t}^{n}-C^{\prime} \phi_{i-1}^{n}+E^{\prime}$

ここに，この式の各係数は下記のとおりである.

$$
\begin{aligned}
A^{\prime}= & -R D_{m}\left(\phi_{i+1 / 2}^{n}\right) \\
B^{\prime}= & 2+R D_{m}\left(\psi_{i-1 / 2}^{n}\right)+R D_{m}\left(\phi_{i+1 / 2}^{n}\right) \\
C^{\prime}= & -R D_{m}\left(\psi_{i-1 / 2}^{n}\right) \\
D^{\prime}= & 2-R D_{m}\left(\phi_{i-1 / 2}^{n}\right)-R D_{m}\left(\psi_{i+1 / 2}^{n}\right) \\
E^{\prime}= & 2 R \Delta m_{z}\left\{D_{m}^{\prime}\left(\phi_{i+1 / 2}^{n}\right)-D_{m}^{\prime}\left(\psi_{i-1 / 2}^{n}\right)\right\} \\
& -2 R \Delta m_{z}\left[D _ { m } ^ { \prime } ( \phi _ { i } ^ { n } ) \left\{\gamma^{\prime}\left(\phi_{i+1 / 2}^{n}\right)\right.\right. \\
& \left.-\gamma^{\prime}\left(\psi_{i-1 / 2}^{n}\right)\right\}+\gamma^{\prime}\left(\psi_{i}^{n}\right)\left\{D_{m}^{\prime}\left(\phi_{i+1 / 2}^{n}\right)\right. \\
& \left.\left.-D_{m}^{\prime}\left(\phi_{i-1 / 2}^{n}\right)\right\}\right]
\end{aligned}
$$

式 (19) において，特に湿潤密度 $r^{\prime}$ とサクション $\phi$ との関係は Fig. 16 に示される式となる. ところで, $r^{\prime}$ と $\vartheta, \phi$ の関係は本来, 土柱の各位置ごとに異なるも のであるが本実験では微小なため無視した.

式 (18)，(19) は末知数 3 個をもつ方程式であり，その 解は Gauss の消去法で求められる. そして，それに伴 う初期および境界条件は，次のとおりである．鉛直上方 に物翼座標 $m_{z}$ 軸の正の方向をとれば,

(1) 初期条件 : $t=0, m_{z}>0, \vartheta=\vartheta_{i}$ （初期体積含水比 分布)

(2) 境界条件 : $t>0, m_{z}=0, \vartheta=\vartheta_{s}$ （飽和の体積含水 比)

$$
m_{z}=\int_{0}^{80}(1 / 1+e) d z, \quad \vartheta=\vartheta(t)
$$

中の実線は, 実験值であり, 破線は式 (16) の計算結果 である.この結果, 両者の関係は，ほとんど一致してお り入力パラメーターの良好さを物語っている. 特に, 式 （16）において湿潤密度 $r^{\prime}$ が $m_{z}$ と により変化する と仮定した考えの正しさをこの図より示唆できる.

Fig. 18 はサクション $\phi$ の実験值と式（17）による 解析結果をプロットしたものである. これより体積含水 比と同様に良好なる結果を示している，つまり，式 (17) の解析に必要なパラメーターの正しさを裏ゔけている.

Fig. 19 において, 式 (4) は一点鎖線, 式 (12) は実 線, 式（16）は破線を表わし，それぞれの值は数值解を

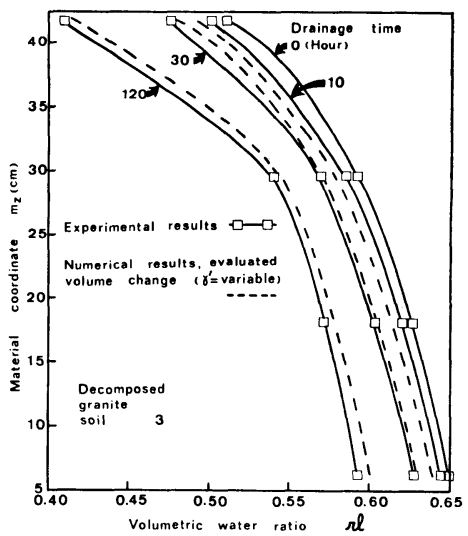

Fig. 17 Comparison of numerical and experimental results of volumetric water ratio after 3rd rewet-drainage test. 


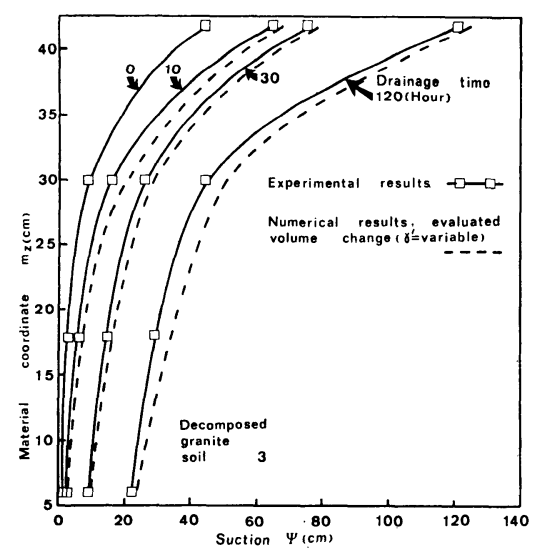

Fig. 19 Comparison of numerical and experimental results of suction after 3 rd rewet-drainage test.

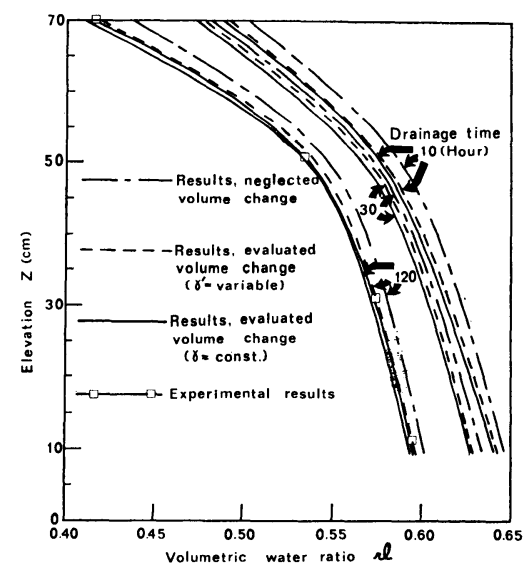

Fig. 19 Numerical and experimental profiles of volumetric water ratio.

示す.ここに，式（4）による值のみ各時刻に対応する間 郘比 $e$ を体積含水比 $\vartheta$ に換算した值を表示した. さて, これらの 3 つの式の結果は, いずれも排水中に時々刻々 と変化する体積含水比の各位置における分布を明確に示 している.ささらに詳しくみると，これらの結果はそれぞ れ若干異なっている.つまり, 体積含水比は各式の中で 間隚変化を考えない式, 間隚変化と湿潤密度を考えるが 密度は変化すると考える式, 間隚変化と湿潤密度を考え るが密度は一定と考える式であり, 後の式になるほどそ の値は小さい，すなわち，体積変化を考えたこの種の式 で湿潤密度 $r$ は取り入れられているものの一定としてい る. しかし, 実際の土中の $r$ は, 体積含水比と沈下によ り変化するものであり, その差が式 (12) と（16）に現わ れている. そして, 図中の 120 時間後の実験值と式(16) の数值解とはよく対応している.

Fig. 20 はサクション $\phi$ に関する数值解で, 式 (5) は一点鎖線, 式（13）は実線，式（17）沙破線をそれぞ

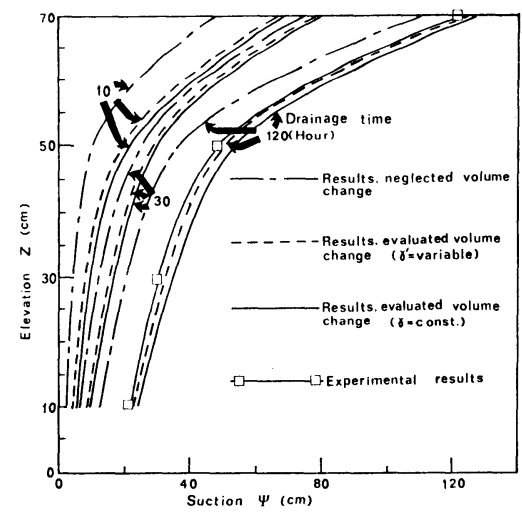

Fig. 20 Numerical and experimental profiles of suction.

れ表わしている.これらの值は，各位置ごとに大幅に変 化しており土の表面に近づくほど大きくなる．やはり， サクションの值においても体積含水比と同様に 3 つの式 による差は明らかである.内訳は，間隙変化を考えない 場合, 間隚変化と湿潤密度の変化を考える場合, 間隙変 化と湿潤密度を考えるが, その密度は一定とする場合で あり, 後の条件ほどサクションは大きくなる、特に, 式 (13) と（17）の差は歴然として扣り, 式（10）に示され た土かぶりポテンシャルの影響を呈している．さらに，

式 (17) の数值解と 120 時間後のサクションの実験值と の一致から， $r^{\prime}$ の変化という仮定の正しさが裏ゔけら れる．以上 6. を総括すると，フィルダムのコア材に風 化度の大きいマサ土を使用する場合, 特に沈下を排水中 に生じさせた結果, その影響が体積含水比とサクション の分布に反映するため, その解析には湿潤密度 $r^{\prime}$ と間 隚比 $e$ の変化を取り入れた式 (16), (17) を用いるべき であり，それらの妥当性を明らかにした.

$r$ 線利用による土中水分計測の今後の課題として, 次 のように考える．マサ土のように湿潤密度の変化の大き い材料については, 精度よく含水比を測定できるが変化 の小さい材料では，かなり困難である. そこで, $\mathrm{H}_{2} \mathrm{O}$ の 水素原子を直接とらえる中性子線を利用する方法が有利 と考えられる. 本解析は, 単に室内実験から得たパラメ ーターを利用したものにすぎないが，現場で含水比やサ クションの経時変化に関するデータの計測が，可能にな ればさらに信頼度も增すであろう。

\section{7. 結論}

本論文は，各種の風化したマサ土の不飽和浸透特性を 明らかにする目的で，土層カラムによる模型実験を行っ た. そして，特に著しく風化した試料の排水過程に生ず る沈下量を測定し体積変化を考えた不飽和浸透方程式に 
基つくく解析を試みた. 得られた主要な結果を要約すると 次のようになる.

（1）土中の含水比注，ガンマ線密度計 $\left(^{60} \mathrm{Co} 100 \mu\right.$ $\left.C_{i}\right)$ で測定したところ, その精度はマサ土のような物性 の複雑な土でもキャリブレーションを正確に行えば，炉 乾燥法に近い值を得ることができ，しかも非破壊で同時 性という利点をもっている.

（2）風化度により, 吸排水時の沈下量は異なり風化 度の大きい試料ほど, その沈下量は大きい. そして, 著 しく沈下の生ずる試料でもその含水比は, 式 (1) に沈下 量から求めた乾燥密度 $\gamma_{d}$ を代入すれば推定できる.

（3）各種に風化したマサ土の相対透水係数 $K_{r}$ は, 有効飽和度 $S_{e}$ の増減により直線的に変化する.

（4）不飽和透水係数, 水分拡散係数, 水分保持曲線 は, いずれも風化度に大きく支配され, 特に沈下の著し い試料では, 浸透中に間隙比の変化を伴うため体積含水 比を用いるべきである.

（5）体積変化を考えた浸透解析は, 従来の式 (12), （13）に基ういていたが，実際の土中では水位変動のた めに湿潤密度は大幅に変化する. したがって, 式 (16), （17）を使用すべきである.

（6）式 (16), (17) で解析した結果, 湿潤密度の影響 は明らかであり, 特に体積含水比よりもサクションに対 して著しい.

参 考 文 献
1）西田一彦・传:々木清一: 水蒸気吸着によるマサ土粒子の 表面特性の検討, 土質工学会論文集, Vol. 15, No. 2, pp. $79 \sim 87,1975$.

2) Nishida, K., S. Sasaki and C. Aoyama : Water Adsorption on Decomposed Granite Soil Particles and Its Influence on Permeability, Technology Reports of Kansai University, No. 20, pp. 153 160, 1979.

3) Matsuo, S., K. Nishida and S. Sasaki : Physical Properties of Weathered Granite Soil Particles and Their Effect on Permeability, Soils and Foundations, Vol. 19, No. 1, pp. 13 22, 1979.

4) Matsuo, S., K. Nishida and S. Sasaki : Physical ProPerties of Soil Particles and Their Effect on Hydraulic Conductivity of Unsaturated Decomposed Granite Soil,
Soils and Foundations, Vol. 21, No. 4, pp. 1 12, 1981 .

5）赤井浩一 - 大西有三・西垣 誠: 有限要素法による飽和 一不飽和浸透流の解析, 土木学会論文集, 第 264 号, pp. $87 \sim 96,1977$.

6）大西有三・村上 毅: 有限要素法による地盤の応力・変 形を考虑した浸透流解析, 土木学会論文集, 第 238 号, pp. 87 96, 1980.

7) Dempsey, B.J. : A Mathematical Model for Predicting Coupled Heat and Water Movement in Unsaturated Soil, Int. Jour. for Numerical and Analytical Method in Geomechanics, Vol. 2, pp. 19 34, 1978.

8) Raudkivi, A.J. and V.U. Nguyen : Moisture Movement in Basecourses due to Temperature Gradients, Ph.D. Thesis, Univ. of Auckland, Report No. 107, 1973.

9) Mitchell, J.K. : Backfill Materials for Underground Power Cables, EPRI Report, pp. 1 73, 1981.

10）土質工学会 : 土工管理とラジオアイソトープ, 土質工学 会, pp. $27 \sim 63,1974$.

11）佐々木清一・西田一彦: マ开土の不飽和浸透特性と圧縮 沈下について, 土木学会関西支部年次講演会集, pp. III4-1 IIII-4-2, 1982.

12）福田 護 : 盛土地盤の浸水に伴ら 沈下とその解析につい $\tau$, 土質工学会論文集, Vol. 17, No. 2, pp. $65 \sim 73$, 1977.

13）軽部大蔵・苗村康造・森田 登・岩崎哲雄：不飽和土の 力学的性質に関する基礎的研究, 土木学会論文集, 第 269 号, pp. 105 119, 1978.

14) Lee, I.K. : Soil Mechanics-New Horizons, London Newnes-Butterworth, pp. 112 157, 1974.

15）河野伊一郎・西垣 誠: 不飽和砂質土の浸透特性に関す る実験的研究, 土木学会論文集, 第 307 号, pp. 59 69, 1981.

16）八幡敏雄: 土壤の物理, 東大出版会, pp. $35 \sim 68,1977$.

17）西垣 誠・河野伊一郎・浅間康史 : 鉛直一次元浸透解析 による不飽和土の浸透特性の吟味, 上木学会全国大会年 次講演集, pp. III-269〜III-270.

18) Smiles, D.E. : One-Dimensional Vertical Flow of Water in Saturated Swelling Soils, Trans. of the 10th Int. Congress, pp. 81 89, 1974.

19）岩片 透: ラジオアイソトープを利用した密度測定方法 （R.I. 法）のフィルダム盛立管理への適用性, 土と基礎, Vol. 23, No. 5, pp. 63〜69.

20）大西有三・西垣 誠: 土中水の不飽和流動, 土と基礎, Vol. 29, No. 7, pp. 65 72, 1981.

(1983.4.22 - 受付) 